mito. De paso ha logrado un estupendo - y ya necesario- docurento sociológico, porque en la América española no hay solamente perros famélicos, sino también perros de raza. Tampoco la presencia del perro entrenado para matar convierte a la novela en una diatriba anticlerical, porque esto seria atribuirle una vulgatidad que no tiene. Lo que Vargas Llosa nos dice, en voz baja y persistente, es que no sólo somos víctimas del egoísmo, sino también de los instintos básicos del hombre. Por eso, y porque los cachorros tienen necesariamente que convertirse en fieras, los amados de los dioses son los que mueren jóvenes.

Esperanza figueroa Amaral

Elmira College

Pollin, Alice M. Concordancias de la Obra Poética de Eugenio Florit. New York: New York University Press, 1967.

Un libro extraordinariamente útil, pero por alguna razón extraña, estética o intuitiva, es también un libro triste. Los estudiantes pueden utilizarlo con facili. dad para completar el estudio de un poeta delicado y sobrio pero duele encontrar la belleza del verso reducida o fórmulas de computadora electrónica. Todos los vocablos que Florit ha empleado, en lista alfabética, en contexto, aparecen en netas clasificaciones. Los adjetrvos, las preposiciones, los verbos, se quedan en las manos como el polvo de las alas de una mariposa atrapada. Casi se siente el capricho de pedir que los poetas, por lo menos los nuevos, no sean sometidos a la inflexibilidad de los artefactos modernos. Este es el ejercicio que necesitamos con Lope, con Calderón, con Góngora - sobre todo Góngora- pero con los poetas vivos, cercanos, es casi sacrilegio.

Se trata de un trabajo de paciencia y dedicación que añade números precisos pero no mucho nuevo a lo que ya sabíamos de la poesía de Florit. El mismo José Olivio Jiménez, que ha preparado un prólogo certero y mesurado, remarca que ya Cintio Vitier había reconocido en el verso de Florit el uso repetido de la palabra ya. Jiménez también anota las otras que más abundan: luz, mar, sueño, tras, años, mañana, antes, luego, alba, amanecer, mediodia y todas las necesarias pero hay desde luego muchas más y la búsqueda es tentadora. Sorprende encontrar la impregnación total del sentido del tiempo en esta poesía de naturaleza tan reservada y discreta. Cerca de 1500 palabras se refieren al tiempo, a la sucesión de los instantes y momentos inexorables, al correr y la marcha de la existencia. Toda esta poesía palpita con este sentido de duración y fugacidad. Después de ya (258 usos) siguen cuando (170), tarde (88), abora (81), ayer (77), dia (65), siempre (57), después (46) escoltadas por minutos, boras, meses, semanas, mientras, años, mañand, antes luego, alba, amanecer, mediodia y todas las necesarias para completar el ciclo. Todo esto es fácil de comprobar pero el secreto mismo de la poesía se escapa al que trate de hallarlo entre las frías cotrelaciones de la máquina. Para descifrarlo, aún con las estadísticas a mano, hace falta un largo trabajo de paciencia, dedicación y percepción.

Es interesante anotar los detalles más salientes, Los animales favoritos, como 
ya sabíamos, son las palomas y las mariposas, pero hay toda clase de pájaros y árboles, hay peces y algunos perros. Hay cisnes, el pájaro sagrado, doce en total que contando los títulos serían catorce. La flor favorita es la rosa, seguida por la violeta. El agua está siempre presente, en mar (184), en agua misma (128), en rio, en arroyo, en regato. El uso total de sol, luz, día, claridad, es sólo ligeramente mayor que el uso de palabras nocturnas: noche, sombra, luna, penumbran oscuridad. Hay también un balance extraño y sugerente entre el uso de muerte y formas del verbo morir y vida y el verbo vivir. Lo mismo pasa con ciertos colores, rojos y grises ( 51 y 51 ) aunque el color dominante es el azul (97). El paralelismo entre silencio y palabra revela otra tentadora dicotomía poética: silencio (106) y el verbo callar (54) se anudan a bablar (29), decir (25), palabra (90) y voz (78). Los que conocen la obra y el sentir de Eugenio Florit pueden emocionarse al comprobar la presencia del niño en todos sus aspectos gramaticales (81). Pero la computadora nos ha reservado una sorpresa. Esta es una poesía de bic et nunc, aquí $y$ abora $(105$ y 81$)$ y las posibilidades filosóficas que esto abre son interminables.

Es una lástima que a pesar de los recursos de la institución patrocinadora el libro no haya sido impreso en manera convencional. Sólo se trata de un trabajo preparado en un modesto laboratorio. Pero hay que hacer notar que es precisa. mente Florit uno de los pocos poetas que ha conservado un respeto renacentista por los tipos de imprenta y que todas sus ediciones han sido hechas con estética $y$ entendimiento. En el contenido algunos detalles han quedado sin ampliar o sin explicarse, como por ejemplo, la omisión de ser y estar y sus tiempos en la concordancia aunque sí aparece el número total de su uso, ya que son importantes para un estudio estructural y especialmente para el estudio de actitudes vitales. También, para el curioso de la técnica, lo serían los contextos de para y por, tanta, tanto y atras voces similares. $\mathrm{Y}$ al psicólogo le hubiera interesado conocer cómo usa Florit el pronombre personal yo (78) dado que es, en español, una palabra clave.

La segunda parte del libro consiste en una reproducción completa de todos los poemas de Florit y se sospecha que el autor ha sido - como de costumbresobradamente generoso con los editores, porque esto no se sospecharía ni del titulo ni de la intención de la obra. Pero con esto se puede constatar que los títulos de los poemas no han sido codificados y esto explica la sorprendente ausencia de trópico entre las concordancias. El uso de mayúsculas en algunas titulaciones y el abuso de quien en el pre-próloga pudieron haber sido sometidos a una editora. lización más cuidadosa. Las estadísticas pudieron haberse aclarado y completadio; no se nos dice exactamente cuántos vocablos ha usado el poeta aunque una suma rápida indica 54,60 en las concordancias y 215 entre los omitidos. Un número sin explicación, añadido al final de las concordancias, parecería indicar que las palabras aparecen en 22665 usos distintos. Las estadísticas aparecen al final de cada grupo alfabético, pero los autores debieron haberles integrado y especificado. El número total de los poemas de Florit, entre 1920 y 1964, es 553, todos aquí reproducidos. Pero no se nos dice nada del poema número uno y se sospecha que esta omisión se deba a la ritual delicadeza poética del propio Eugenio Florit.

\section{Elmira College}

ESPERANZA FIGUEROA AMARAI 